\title{
103 画像による渦キャビテーション解析
}

$$
\begin{aligned}
& \text { 東北大学大場光太郎。, 祖山均, 武田涉, } \\
& \text { 石原正, 猪岡 光, 大場 利三郎 }
\end{aligned}
$$

\section{High-Speed Observations of Highly Erosive Vortex Cavitation around a Butterfly Valve}

\begin{abstract}
Kohtaro OHBA*, Hitoshi SOYAMA**, Sho TAKEDA**, Tadashi ISHIHARA*, Hikaru INOOKA* and Risaburo OBA**
\end{abstract}
In order to clarify the mechanism of the severe erosion mainly resulted by the singular vortex cavitation, we carefully try to observe the vortex cavitation associated with the erosion around a butterfly valve by means of a high-speed video-camera, whose framing rate is 40500 per seconds. The velocity of cavitating flow are measured by using the digital-image processing-technique. It is worth noticing that the vortex cavitation develops in the boundary region between the main flow region, i.e., the orifice-jet, and the recircurating region. The cavitating vortex core consists of several tiny vortex cavitation. And the rotating velocity of the highly erosive vortex cavitation can be also detected by the technique.

\section{1. 緒 言}

バ夕フライ弁はその棈造が簡単で,その制御特性も優れているので,種々のプラントに多用 されているが,升の大形化, 極限環境下での使用とともにキャビテーション壊食(1)(以下単に壊食 という)墚刻な問題となってきており,なかでも激しい壊食 ${ }^{(2)(3)}$ 効果的抑制法の確立が工業 界から要請されている。

これまでバタフライ弁まわりの流れパターン観察(4)やキャビテーション衝慗压測定(5)から,弁 まわりの激しい壊食の主因はオリフィス側下流に発生する特巽渦キャビテーションであり, 発 生領域はオリフィス嗔流により生ずる高せん断領域に限定されることが判明しているが,特 異渦キャビテーションの発生が非定常的であるために, その詳細な挙動についてはいまだ末知 なる点が多いまた遠心ポンプや二次元翼形に生ずる激しい壊食も同様な渦キャビテーショ ンによって引き起こされる(6) (8)ことから,このような高壊食性渦キャビテーションの詳細な挙動 を究明することは䧇食機棈解明の観点からも非常に有意義であろう.特に、これらの渦キャビ テーションの発生が非定常的であり,かっ,その渦キャビテーションの渦コアが数 $\mathrm{mm}$ から数 $\mathrm{cm}$ 小さいために, 従来の方法による流速や代力の测定は困難であったが, キャビテーション気泡(以 下単に気泡というによる流れの可視化を利用して, 画像処理法(9) (11)による渦キャビテーション の举動の詳細な解析の可能性が生している.

よって本報では, 高壊食性渦キャビテーションの挙動解明の第一歩として,バタフライ弁のまわ りの流れを取り上げ，壊食に係わるキャビテーションの様相を高速度ビテオカメラ等で観察し， また,画像処理法により高壊食性渦キャビテーションまわりの局所的速度分布の計測を試みる。

* Department of Mechanical Engneering, Tohoku University, Aramaki aza Aoba, Aoba-ku, Sendai, 980, Japan

** Institute of Fluid Science, Tohoku University, 2-1-1 Katahira, Aoba-ku, Sendai, 980, Japan 


\section{2. 実験装および置法}

実験装置およひ測定部には, Fig.2に示す既報 ${ }^{(5)(12)}$ と同じ回流式試験水槽を用いている.なお， 供試弁体には,典型的な高壊食性渦キャビテーションが発達するFig.1に示すような偏心形弁体 を用いている。

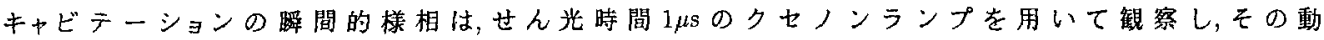
的様相は，最高速度40500コマ/s, 曼高画素数 256 画素× 256 画素の高速度ビデオカメラ(コダック製， コッダクエクタナロロモーションアナライザーモテルHS4540) で, 1.5kWのシネキングライトラン プ(色温度 $3200 \mathrm{~K})$ を用いて撮影している。

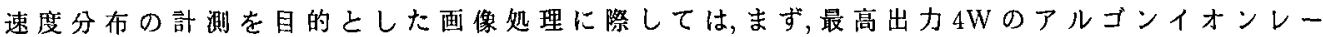
ザを光源 (Spectra-Physics 製, Head:2017-04s, 管:0026-0006, 電源:2550, マルチモードで使用)としたレーザ ライトシート光(日本レーザー製, SLSレーザライトシートSLS-01)を厚さ $2 \mathrm{~mm} を$ 使用し, 三次元 流れ中の任意の二次元流れを高速度ビデオカメラで撮影し, 各コマごとにディジル画像入

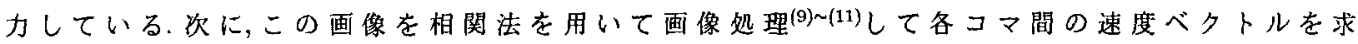
めている.なお，画像処理のアルゴリズム等の詳細については既報(11)を参照されたい。

キャビテーション倸数 $\sigma$ は，

$$
\sigma=\frac{\left(P_{2}-P_{v}\right)}{\left(P_{1}-P_{v}\right)}
$$

と定義し,ここで, $P_{1}$ と $P_{2}$ は，それぞれ弁体の $2 D$ 上 流と $8 D$ 下流での静区である.弁開度 $\alpha_{v}$ は，弁体面 と流扎に平行な璉直面がなす角度で定義する. 試 䟻条件は,特異渦キャビテーションが顕著に発生す 万升開度 $\alpha_{v}=40 \mathrm{deg}, \sigma=1.5$ と ᄂ, 上流側流速 $U_{1}=4.0$ $\sim 6.0 \mathrm{~m} / \mathrm{s}$ としている.

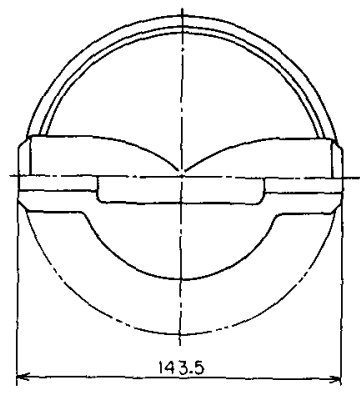

Fig.1: Test Valve

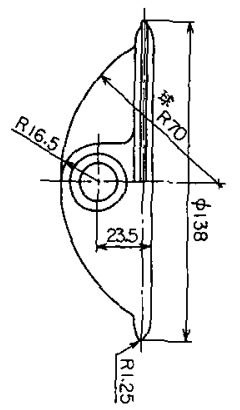

淧

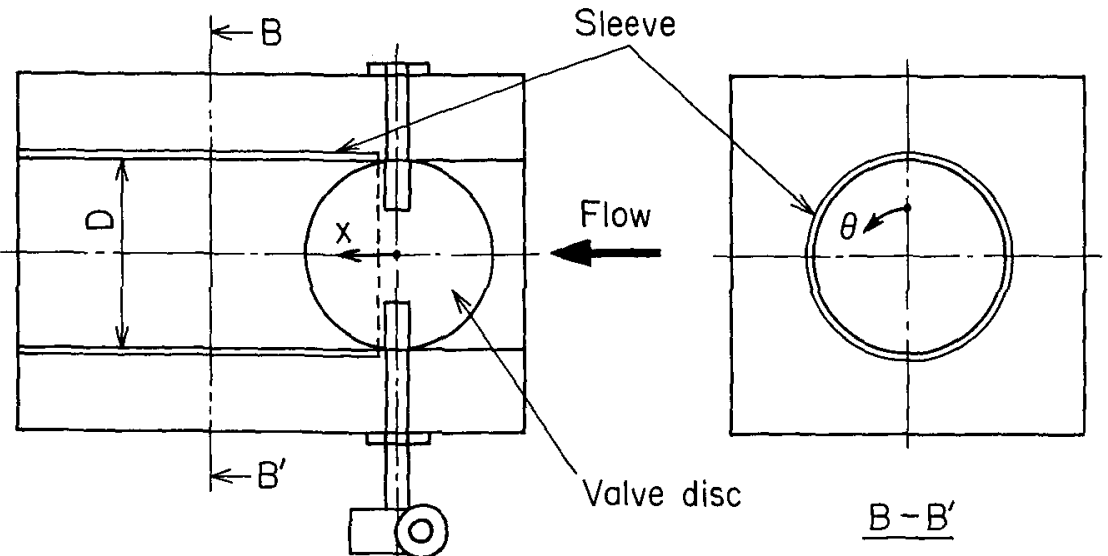

Fig.2: Experimental Device. 


\section{3. 実験 結 果}

\section{1. 特異渦キャビテーションの挙動}

Fig.3には, $4500 コ マ / \mathrm{s}$ の高速度ビテオカメラで撮影した弁体まわりのキャビテーションの様相 を示す.なお, Fig.3では, 撮影したコマから2コマこととに抜き出して示している. 各コマの右側に 輪郭が白い半楕円形状に見えるのが弁体上の上流端から生じたキャビテーションである. 并体 および弁棒まわりの盛り上がり部に生じたキャビテーションがオリフィス噴流に沿って下流に 放出され, 高せん断領域(4)(5)(12)で特異渦キャビテーションが生じている. 特に, 図中の $t=0 \sim 1.33$ $\mathrm{ms}$ の弁体下半部分の渦キャビテーションに顕著に現れているように, 細い渦キャビテーション が合体して特異渦キャビテーションへと成長する椂相が見て取れよう.すなわち,特異渦キャビ テーションの形成要因の一つは,このような渦キャビテーションの合体であろう.そもそも, 激し い壊食の壞食率は, 渦キャビテーションのサイズが大なるほど壊食率が著しく増大する棌ので, 特異渦キャビテーションのサイズが大となる場合について特にその発達過程を究明してみよ う. Fig.3の左上半部分に生じている特異渦キャビテーションに注目すると, 上流側流速 $U_{1}=5.1$ $\mathrm{m} / \mathrm{s}$ であり,多くの特異渦キャビテーションが下流に流出しているにも係わらず, ほほ同位置に 停在して, 特異渦キャビテーションまわりの気泡量が著しく大きくなっている.

Fig.4には, 4500 コ/s (図中 4 コこととに示す) で渦コアの方向から拡大して撮影し, Fig.5に は, 瞬間写真でとらえた典型的な特異渦キャ ビテーションの様相を示す. Fig.4, 5の Flow は, 主 流の流れ方向を示している. Fig.4から気泡が 渦コアを中心として変形しながら回転し,や がて凝集して崩壊する様相がよく見て取れ る.Fig.4, 5より,特異渦キャビテーションの渦コア は,多数の気泡から構成されており,渦コアの 形状は, 偏平, かつ, 捻れている.これは, 同程度 の渦度を持つ 2 個の渦が絡み合ってッイストし ている様相と類似しているから,前述した特 異渦キャビテーションが複数個の渦キャビテー ションが合体・成長している事実を裏付けてい る. 特に, 実際に壊食を生ずるのは管壁面であ るから,特異渦キャビテーションの管壁面近傍 の様相に着目してみる. Fig.5において, 特異渦 キャビテーションが管壁面に接する位置では, 管断面が円形であるために, 渦コアの下端で 黒い長楕円形に見えている.なお,このように
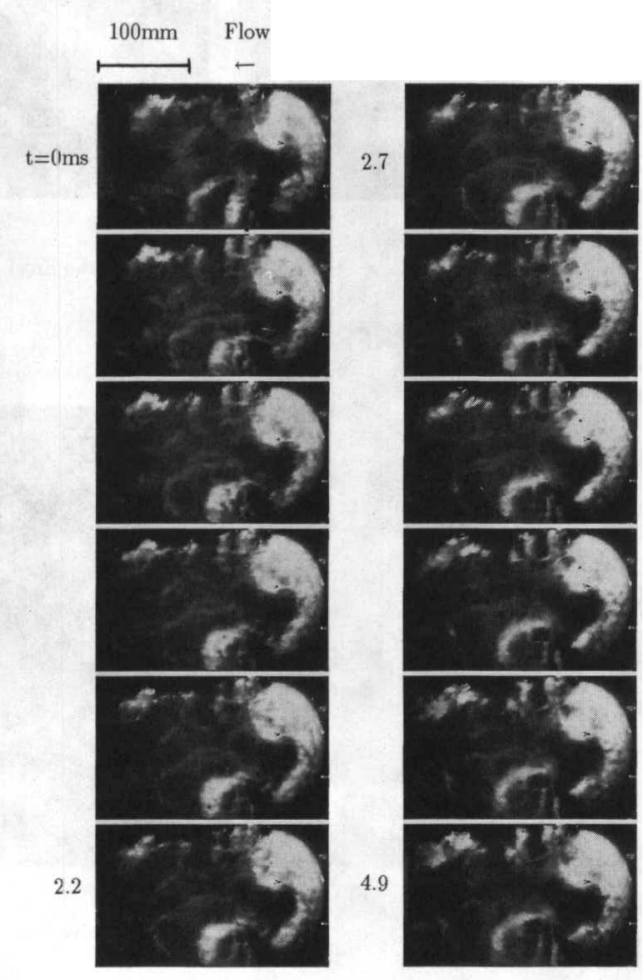

Fig.3: Aspect of Cavitation Changing with Time.

黒く見えるのは, 特異渦キャビテーションが管壁面に接しており,かつ, 管壁面近傍では気泡が多 数集まって気泡密度が極端に大きくなり, 単一キャビティに近い状態になっているからであろう. 


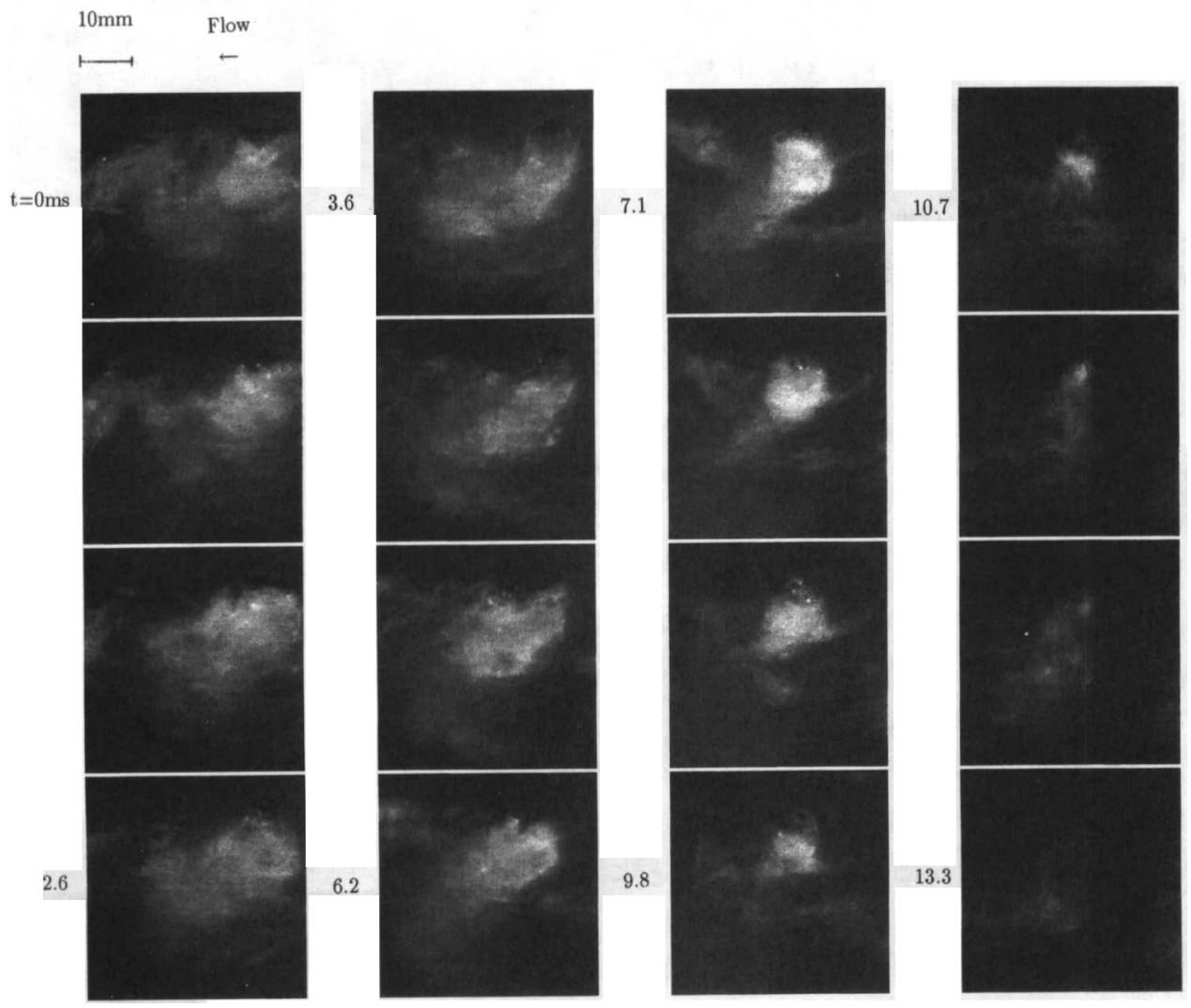

Fig.4: Aspect of the Erosive Vortex Cavitation.

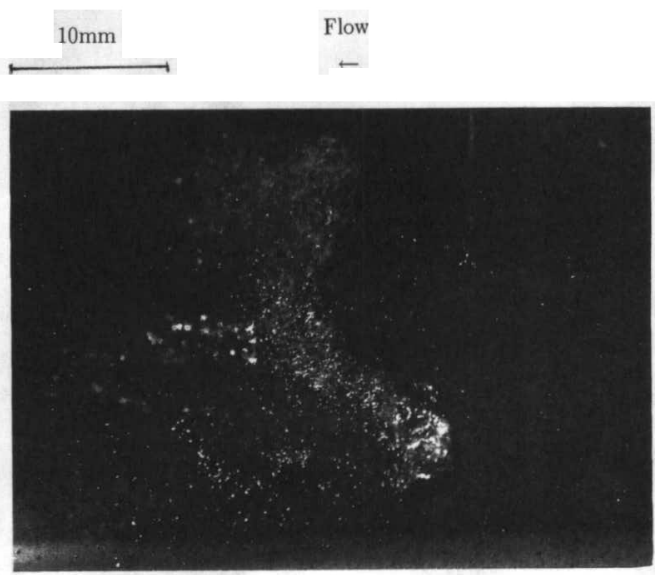

Fig.5: Highly Erosive Singular Vortex Cavitation. 


\section{2. 特異渦キャビテーションまわりの局所的流速分布}

Fig.6には,レーザライトシート光を用いて2250コマ/sの高速度ビでオカメラで撮影した特異 渦キャビテーションの様相と,それらの画像を相関法を用いて画像処理して求めた速度ベクト ルとを, $U_{1}=5.1 \mathrm{~m} / \mathrm{s}$ の場合について示す(Flow は主流の流れ方向).なお, Fig.6は, Fig.4と同様の并体 下流の上半部領域を 256 画素 $\times 256$ 画素で撮影し,特異渦キャビテーションの渦コアを中心とし て140画素 $\times 140$ 画素の部分を㹡大して示している.図中,主流の流れ方向をFlowで示す.なお， 速度ベクトル図の1コマ目は画像の1コマ目と2コマ目の相関から求めており,以下の各コマ は順次そのように求めている.画像おょび速度べクトルから,まず,気泡密度の高い領域(渦 ア）市心として多数の気泡および渦コアが回転し,やがて回軽中心部分に向かって収縮して いる様相が明瞙に見て取れる。すおち, 画像処理を用いた本解析方法により直径数 $\mathrm{cm} の$ 渦 キャビテーションの渦コア近傍の局所的流速の計测が可能であることが示されたなおお, 計測 した特異渦キャビテーションの回転周速度は上流侧流速 $U_{1}$ の数十\%であり,また,特異渦キャビ テーションの崩壊時における気泡の㠜集速度は $U_{1}$ と同オーダである.

以上のことから, 特異洞キャビテーションのサイズが著しく增大する原因の第1は渦キャビ テーションが合体すること,第2は逆流域で比較的長い成長時間をかけて自転しながら渦コア に多くの気泡を取り込まれることであろう。

\section{4. 結 言}

バタフライ弁まわりの流れを取り上げ壊食に主として係わる特異渦キャビテーションを詳 細に観察し, 画像処理法により特異渦キ+ビテーションまわりの局所的速度分布を計湘した粘 果, 弁体まわりに生ずる洞キャビテーションが, 逆流域とオリフィス噴流との境界の高せん断領 域で主流方向に流れながら発達・合体し，逆流域に渦キャビテーションが流れ込んで渦コアを 中心に回転する間に更に気泡を渦コアに取り込んで高壊食性特異渦キャビテーションとなる 事実が判明した。

\section{参考文献}

[1] Hammitt, F.G., Cavitation and Multiphase Flow Phenomena, (1980), McGraw Hill, 220.

[2] Soyama, H. 加 5 名, Proc. 15th Int. Sympo. of IAHR, Belgrade, (1990-9), H4.

[3] Soyama, H. ほ 加名, Proc. Cavitation and Muliphase Flow Forum, ASME, Portland, (1991-6), 193.

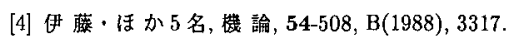

[5] 谷·ほ 活3名, 機論, 57-537, B(1991), 1525.

[6] 柤山・ほか2名, Proc. Srd Int. Symp. on Cavitation,

[7] 伊藤・ほか 6 名, 機論, 54-506, B(1988), 2727.

[8] 祖山, 機論, 58-555, B(1992), 3366.

[9] 木村・ほ加2名, 計測自動制御, 23-2(1987), 101.

[10]木村・は加名, 流れの可視化, 7-26(1987), 297

[11] 大場・ほか2名, 流れの可視化, 9-33(1989), 145.

[12] 谷・ほか 4 名, 機論, 58-553, B(1992), 2645. 

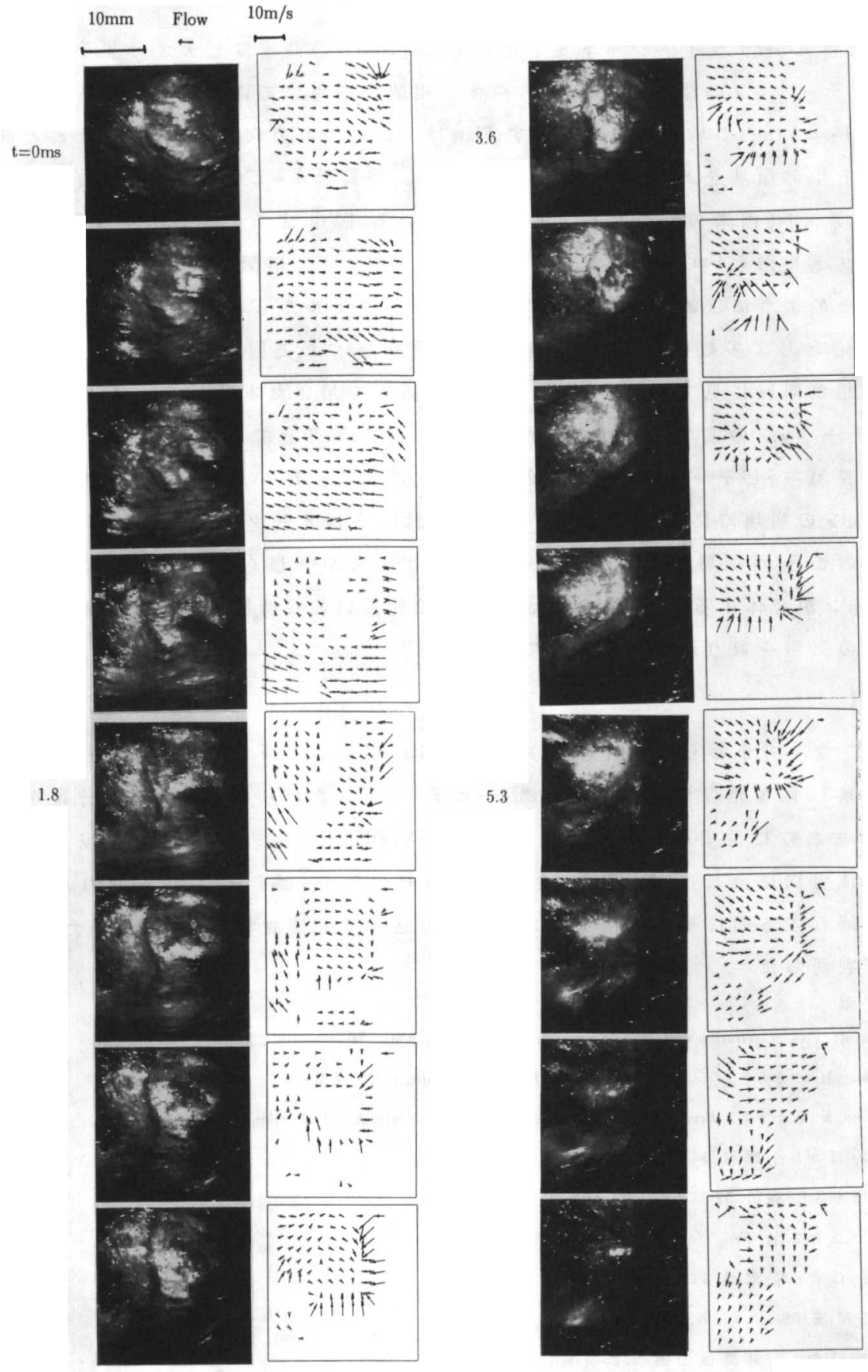

Fig.6: Aspects Observed by Laser Light Sheet and Velocity Vector of the Vortex' Cavitation 